\title{
Energy blockade of Donbass and its consequences for Ukraine
}

ABSTRACT: The annexation of Crimea and military operations that began in eastern Ukraine in April 2014 were the cause of the growing threat to Ukraine's energy security. In terms of coal supplies, Donbass is of key importance for the country's economy. Despite military operations on the east, illegal trade with the occupied territories was flourishing. This situation led to an increase in dissatisfaction amid certain social strata, as well as among volunteer battalions participants who took part in the military operations in Donbass and were the initiators of the Donbass blockade. The main purpose of the study to analyse the specific of the development of coal industry in Ukraine and the main reasons of the blockade of Donbass and its consequences.

KEYWORDS: blockade, Donbass, Ukraine, coal

$\triangle$ Corresponding Author: Oksana Voytyuk; e-mail: oksana.voytyuk@uwb.edu.pl

1 Institute of History and Political Sciences, University in Bialystok, Białystok, Poland; ORCID iD: 0000-00016452-2893; e-mail: oksana.voytyuk@uwb.edu.pl 


\section{Introduction}

The Donetsk Coal Basin is one of the largest in the world. It is located in two countries Ukraine and the Russian Federation. In Ukraine, the basin covers a part of the Dnipropetrovsk, Donetsk and Lugansk oblasts, and in Russia - the Rostov region. The total area of the basin within the borders of the Ukrainian state is $50,000 \mathrm{~km}^{2}$. Coal resources in Donbass are at a depth of up to 1,500 meters and are characterized by a high methane concentration. There are currently 30 mining and industrial regions in Donbass with various coal mining conditions. Almost all types of coal are available in the region. Coal contains high amount of sulfur - up to $3 \%$. Most of the coal layers that occur at a small depth were exploited in Soviet times. Currently, the extraction of coal is carried out at a depth of 500 to $1000 \mathrm{~m}$, which increases it cost and carries a high threat to the life of miners. A high risk of sudden release of rocks and gas (methane) ${ }^{*}$ in more than $1 / 3$ of the mine (Kazansky et al. 2017).

After the collapse of the USSR, Ukraine received about 283 mines in the Donbass and several dozen in the Galican-Volyn Coal Basin. The collapse of the Soviet Union contributed to the breakdown of economic ties, accelerated the pace of decline in industrial production and reduced the demand for coal in the former Soviet republics. During the first five years of Ukraine's independence (1991-1996), coal production decreased twice (Chart 1). In 1991, production accounted for 63.0 Mtoe, and in 1996 - 33.1 Mtoe. In the years 1996-2000, the restructuring of the coal sector began, as a result 83 mines were closed but production slightly increased to 36.1 Mtoe in 2000 . Such a low level of coal production is explained by the deepening economic crisis, unsatisfactory technical conditions of the mines, deterioration of the working conditions of miners. In 2000 , the privatization process began, as a result most of the prospective mines were handed over to private hands. However, this did not significantly affect the extraction of this resource. In 2013, 53 mines were in private hands and 82 in state hands (excluding the illegal "kopanky" mines) (Kazansky et al. 2017).

Since 2014, coal production continued to decline from 36.6 Mtoe to 14.4 Mtoe in 2017. With the decline in production, consumption also decreased but still remained higher than the level of production. During the entire period of independence, Ukraine's coal consumption exceeded production, with the exception of 1991. As a result of the Donbass war and taking over by the self-proclaimed republics of the largest coal mines, the production and consumption of coal decreased, but the difference between consumption and production increased (consumption exceeds production almost twice).

\footnotetext{
* Methane is very dangerous, because it creates a fire hazard and can cause underground explosions, which often results in human sacrifices. Methane from coal layers is almost impossible to recycle and huge amounts of it are thrown into the air through special ventilation systems, which in turn has a very negative impact on the natural environment of the region and significantly increases the level of greenhouse gas emissions.
} 


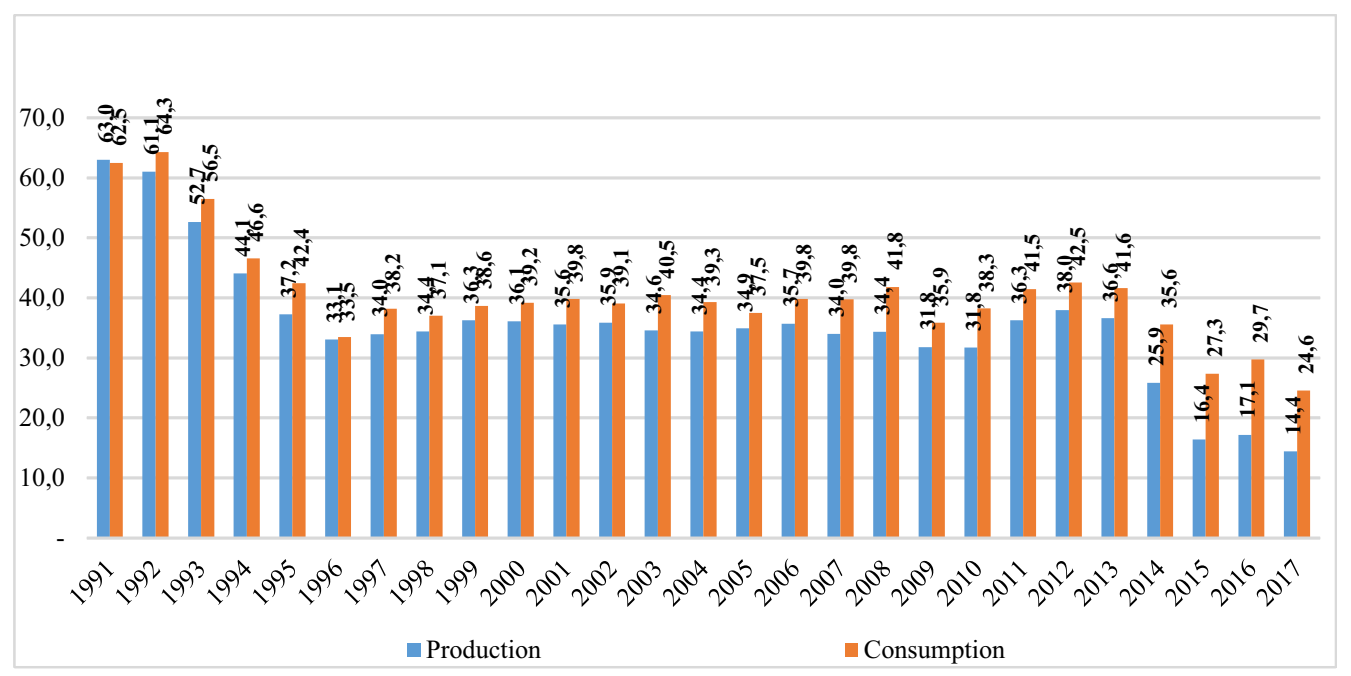

Chart 1. Dynamics of production and consumption of the coal in Ukraine in 1991-2017 [Mtoe]

Source: own study based on BP international statistics review 2017

Wykres 1. Dynamika produkcji i konsumpcji węgla w Ukrainie w latach 1991-2017 [Mtoe]

\section{The role of DTEK and its meaning}

After the privatization process stopped, the share of state enterprises in coal mining was $28 \%$, the remaining $72 \%$ were private enterprises (Chart 2) (Bobro 2015). Most of the state coal mines (a significant part are low-power mines with difficult mining and geological conditions) are inefficient and need subsidies from the state budget. At a time when all non-state enterprises in this sector are profitable (they do not receive state subsidies), the use of production capacities on them is more than $90 \%$, and labor productivity in coal production is also 2-3 times higher. In addition, miners' wages are $20-25 \%$ higher in private mines than in state mines (Popovych 2013). Mine's owners were interested in improving the quality of the work and increasing the scale of coal production, that's why investments into the private mines were greater than in those that belonged to state.

The most prospective mines were in the hands of the DTEK company (Fig. 1). The company is the largest investor in Ukraine and is part of the SCM group whose shareholder is Rinat Akhmetov (DTEK 2017).

DTEK is a key player on the Ukrainian coal market. The company has 31 mines, 13 factories for coal enrichment, 9 thermal power plants and 2 heat and power plants* (DTEK 2017). In 2011,

* Zuyiv thermal power plant is beyond the control of DTEK. 


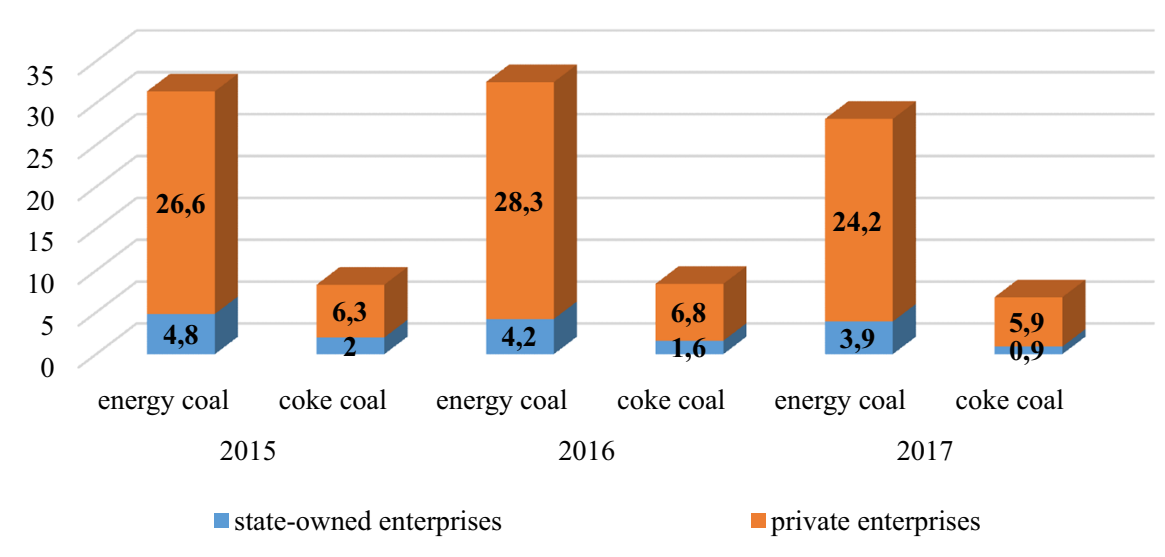

Chart 2. The share of private and state-owned enterprises in the coal production in Ukraine [million tons] Source: own study based on (DTEK 2017)

Wykres 2. Udział prywatnych i państwowych przedsiębiorstw w produkcji węgla w Ukrainie [mln ton]

DTEK incorporated the two most powerful companies in the Lugansk region - Rovenky and Sverdlovantratsyt. The position of DTEK on the Ukrainian coal market became dominant, and a significant part of the state's energy sector was controlled by one private company. Moreover,

\section{Operational holding companies and areas of activity}
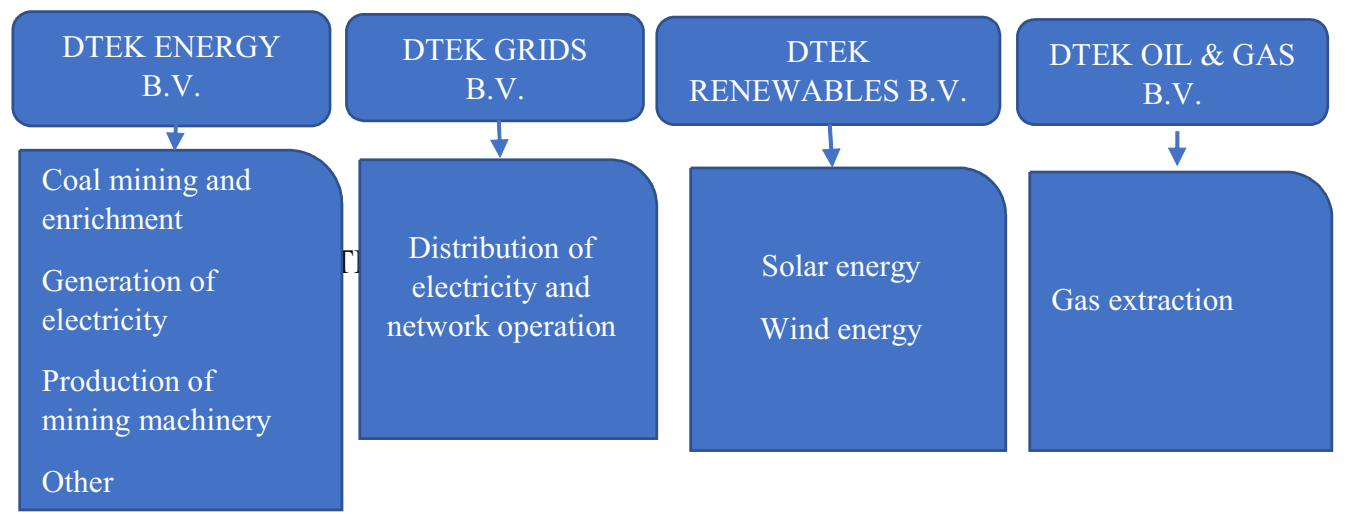

Fig. 1. Structure DTEK B.V.

Source: DTEK 2017

Rys. 1. Struktura DTEK B.V.

100 
DTEK strengthened its position after the war began in Donbass, when the carbon sector suffered a breakdown. Currently, the share of DTEK in total extraction exceeds 67\%* (Kazansky et al. 2017). Private mines provide the demand for raw materials in industry and energy, while state mines are not profitable and most of them are gradually bankrupt. The collapse of state mines initiated the process of illegal coal mining from the upper layers. Over time, the illegal extraction reached an industrial scale, and control over the production was taken over by Viktor Yanukovych's entourage** (Ibidem).

\section{Donbass blockade}

Since the start of hostilities in Donbass trade with the occupied territories continued. Some representatives of the political forces call it "business on blood". It is believed that both sides of the conflict (authorities in Kiev and authorities in self-proclaimed republics in Donbass) were interested in getting some profits (Text 2017). On December 16, 2016 veterans of volunteer battalions, especially "Donbass" and "Aidar" announced an ultimatum, if within 7 days all Ukrainian prisoners of war were not released, the total blockade of occupied territories in the east of the country would begin. The volunteers message was not heard by the authorities of the self-proclaimed republics and the liberation of prisoners did not take place. In reaction to such behavior of the DPR/LPR leaders, veterans of "Donbass" and "Aidar" blocked roads and rail routes towards the occupied Donbass. It was a voluntary action and not coordinated with representatives of the Ukrainian authorities, however, some representatives of political forces representing interests in the Ukrainian parliament, for example, the "Samopomich" party, joined it (Gore 2017). The direct blockade began on January 25, 2017 by blocking the Lugansk-Lysychansk-Popasna railway, and on January 30, 2017, the railway tracks were blown up on this section (In Lugansk

* DTEK belongs to the SCM group (System Capital Management), it was founded in 2000 for asset management in mining, metallurgy and power engineering. Along with the expansion of activities within the group, other business sectors have emerged.

** Since 2007, illegally extracted coal has been sold through the State Enterprise "Coal of Ukraine" under the guise of mining at a high cost mine. The difference between the sales price and the cost of production was covered from the state budget. From 2007 to 2011, the legalization of illegally extracted coal took place mainly through two stateowned companies - "Sverdlowantracyt" and "Rovenkyantracyt" in the Lugansk Oblast, until the two organizations were included in the structure of DTEK as a concession. As long as coal associations were owned by the state, millions of tons of illegal coal were legalized from the "rat hole mines" (kopanky). The period of Viktor Yanukovych's rule is characterized by the centralization of corruption processes in the coal industry. The president's clan managed to take over almost the entire illegal sector. Coal from "kopanky" most often found its way to state-owned combined heat and power plants. In March 2013, the company "Donbass Oil”" associated with Viktor Yanukovych, Jr. won the tender for the supply of 153,500 tons of coal to the state company "Donvuglerestructuryzatsiya". The Donbass Oil Company, not having its own mines, was selling coal which was bought from unknown sources. This means that it acted as a company - a "shell company". In this way, the state, headed by V. Yanukovych, bought coal from the president's son (Yanukovych, Jr.), which was mined in "kopanky", which operated under his own protection. 
2017). The energy blockade of Donbass resulted in the introduction of a state of emergency in the Ukrainian energy sector ${ }^{*}$ (Solonyna 2017). The main reason for this was the suspension of supplies of anthracite to thermal power plants located in non-occupied territory of Ukraine.

Before the outbreak of hostilities in Ukraine 150 working mines, 90 of them were in state ownership. Currently, 83 mines (57\%) are outside the control of the Ukrainian authorities. In the self-proclaimed republics, all mines (55) producing anthracite coal "A" remained, which was the cause of the severe shortage of this type of fuel in Ukraine (There are 2015). Seven out of 14 thermal power plants, due to the technological cycle, specifically require this type of coal (Fig. 2).

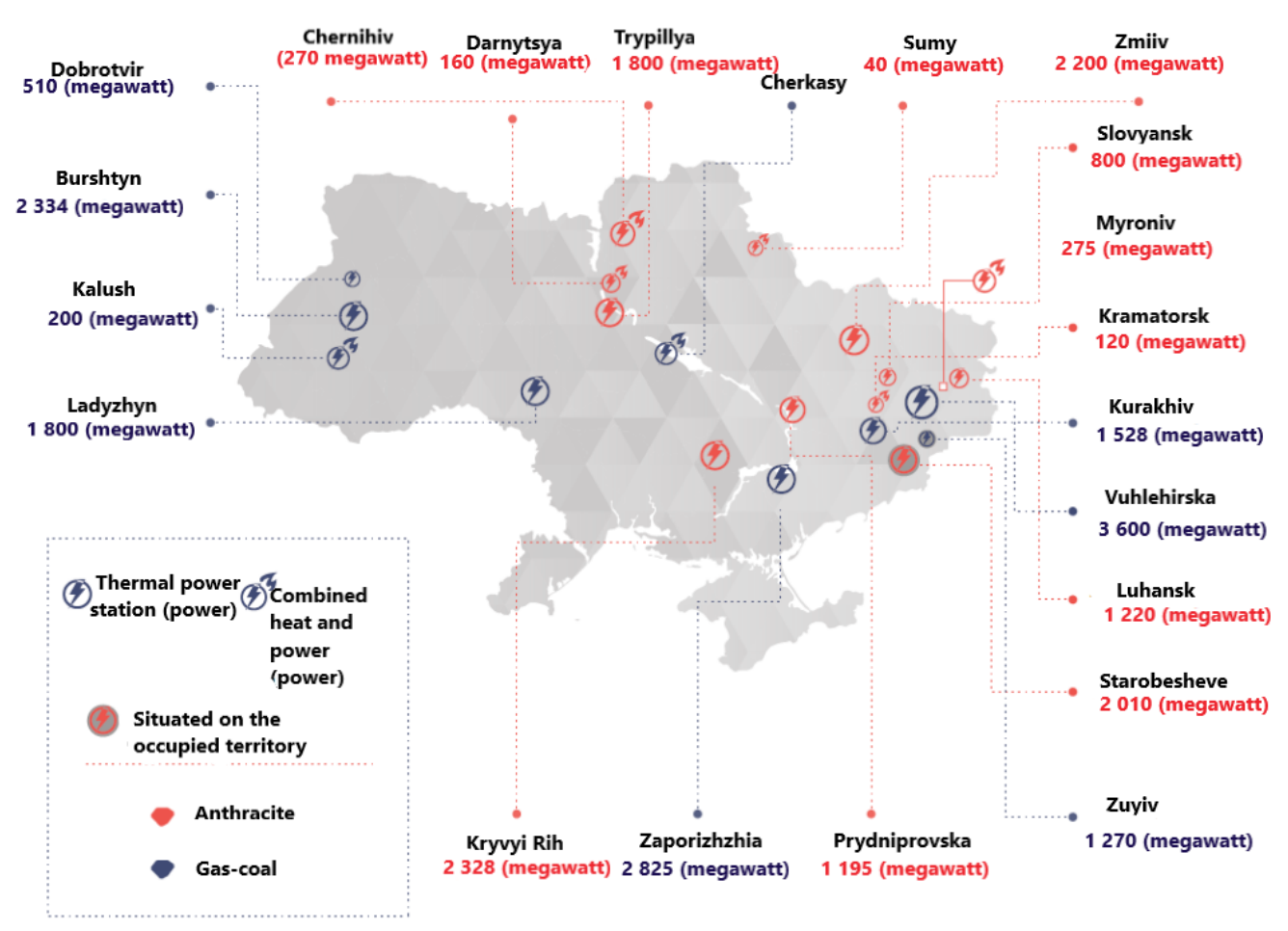

Fig. 2. Heat and power stations and thermal power stations of Ukraine, which require the brand "A" coal Source: Overview 2017

Rys. 2. Elektrociepłownie i elektrownie cieplne Ukrainy, wymagające węgla marki „A”

In view of the situation it raised the question why the Ukrainian government did not take any steps to modernize or diversify supplies to thermal power plants could operate on coal gas brand "G", which is in surplus? Replacing the "A" brand coal from Donbass by means of its import

* To avoid energy collapse, Ukraine has increased electricity production at the expense of nuclear power plants. Electricity production using nuclear power plants increased from 47 to $60 \%$. 
from South Africa or by exchanging it with the already mentioned "G" brand coal. According to experts, the modernization of one power plant can last from 6 months to a year. According to statistical data, carbon-based thermal power plants provide up to $30 \%$ of electricity, which requires 24 million tons of coal per year, of which 9 million tons is anthracite. It follows that the role of anthracite in the energy balance is only $10 \%$ of the energy needs of the state (Solonyna 2017). At present, only one Lugansk thermal power plant works from 7 thermal power plants. Suspending the operation of this power plant may result in power outages in regions adjacent to war areas ("gray zones") (Pyvovarov 2017).

The first attempts to replace Ukrainian coal by African were taken in 2014 and were successful. However, coal from South Africa is more expensive, which significantly increases the price for electricity. Ukraine will be forced to pay USD 20 more for each ton, and the delivery time of it from South Africa to Ukraine lasts from 50 to 80 days. In addition, for the combustion of this type of coal, it is necessary to mix it with anthracite. Coal from the occupied Donbass is cheaper and of better quality. In this situation, the most optimal variant for Ukraine would be replacement fuel on thermal power stations. February 16, 2017, Petro Poroshenko, President of Ukraine signed a decree on the implementation of the decision of the National Security and Defense Council of Ukraine "On urgent actions to neutralize the threat to Ukraine's energy security and increase the protection of critical infrastructure". Among the basic activities, it converting thermal power plants from "A" brand coal to "G" brand coal is planned (DTEK 2018). This process requires significant financial costs, but the long-term perspective is the most profitable. The Zmiiv thermal power plant (Kharkiv region) is the first one that changed the type of fuel, it is one of the oldest power plants. The modernization lasted for 1.5 years and its costs amounted to about UAH 200 thousand (Fig. 2) (Gorban 2017). It was the first project from the exchange of units working on anthracite into gas coal. The entire process from idea to implementation lasted about two years (Gulya 2017). According to the data for 2018, Ukraine has completely modernized three thermal power plants that can work on different types of fuel (Centrenergo TPP units 2018). These are the: Zmiiv, Trypillya and Prydniprovska thermal power plant. In 2019, DTEK has planned a modernization of the Kryvyi Rih thermal power plant, which currently works on " $A$ " brand coal. The DTEK program, the aim of which is to shift power units of thermal power plants from anthracite into gas coal has reduced the consumption of imported "A" brand coal for one and a half times - from 3 to 2 million tons per year. Ukraine has been importing coal for electricity production since the beginning of the armed conflict in Donbass. In March 2014, anthracite production in Ukrainian mines was halted, which resulted in increased imports. In 2017 imports were the largest in four years of war and were about 5,090.8 thousand tons of coal. For the first time in the history of Ukraine, coal supplies from the United States began (Chart 3). According to statistical data, regardless of the war in Donbass, Russia was the main supplier of the energy coal brand "A", South Africa was in second place, the US and Poland were third and fourth respectively (DTEK 2017). 


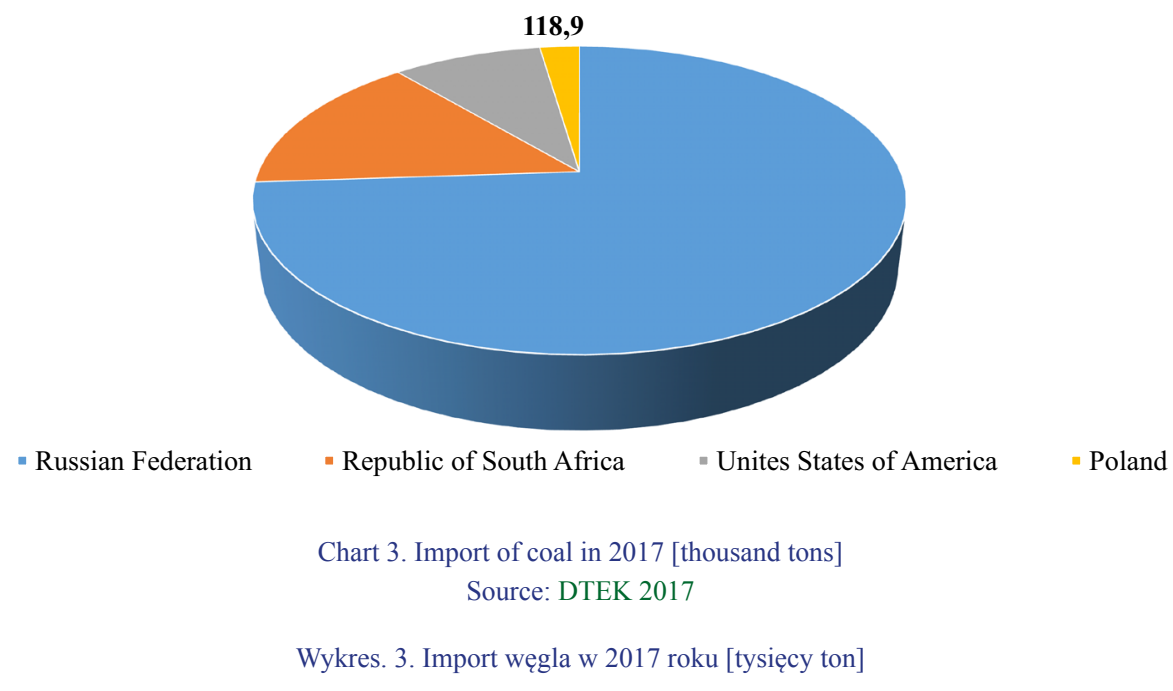

\section{Dimensions of Donbass blockade}

The Donbass energy blockade had several dimensions - political, economic, information and security. In addition, the blockade affected the image of Ukraine on the international arena. In the political dimension, the blockade was supported by:

$\checkmark$ social movements that had political ambitions and intend to take part in parliamentary elections;

$\checkmark$ political parties that did not enter the Ukrainian parliament at the time of the 2014 elections;

$\checkmark$ political parties that are present in the Ukrainian parliament, but their ranking is not high, for example Samopomich*.

In addition, the goal of the blockade was to weaken the political position of the President of Ukraine and show the lack of a developed strategy for action on areas temporarily occupied. In the economic dimension of Donbass blockade led to:

$\downarrow$ losses of energy enterprises, mines and others;

$\checkmark$ introducing a state of emergency in the energy sector;

$\checkmark$ problems with the supply of the "A" brand coal and for switching thermal power plants from this type of coal to "G" brand coal;

$\checkmark$ economic losses;

$\downarrow$ disturbances in the energy chain;

* The Samopomich Party, due to the problem of "garbage" in Lvivlost a lot of support. 
$\checkmark$ halt the work of energy companies;

$\checkmark$ social tensions and an increase in the level of unemployment in the occupied territories;

$\downarrow$ revealing the scale of corruption and illegal trade with the occupied territories (Zakharchenko 2017).

One of the reasons of the Donbass blockade was uncertain position of Rinat Akhmetov regarding the conflict in Donbass. The Donbass blockade strongly hit Akhmetov's business interests. There are speculations (in business and in political environment of Ukraine) that one of the goals of the blockade was to weaken the economic activity of SCM in the occupied territories. The blockade has not only affected the interests of the oligarch, but above all citizens who work in companies belonging to the SCM group (Радчук 2017). On March 15, 2017, the SCM group reported that it had lost control over all assets in the occupied territories (SCM group 2017). As a result of the Donbass energy blockade, in March 2017, DTEK lost control over DTEK "Rovenkyantracyt", DTEK "Sverdlovantracyt", the Zuyiv thermal power plant and several other energy companies. The general director of DTEK M. Tymchenko said that the loss of assets and the "nationalization" of assets by self-proclaimed republics is the result of a political dispute, the hostages of which became Ukrainians, Ukrainian business and the Ukrainian economy. Enterprises working in areas beyond the control of Ukraine are part of a integrated Ukrainian economic infrastructure. The disruption of the production chain caused problems with the sale of coal from the occupied territories, the deterioration of difficult situation of the miners employed there. Illegal coal sales on international markets have serious consequences for all parties - both sellers and buyers. Such a situation results in stopping the work of enterprises, increasing unemployment, declining incomes and increasing social unrest on both sides of the demarcation line. Within three years since the start of hostilities in Donbass, DTEK operated exclusively in the legal field of Ukraine. In 2016, over UAH 2 billion of taxes were paid to the budget (DTEK 2017). A significant part of DTEK and MetInvest enterprises are integrated in the only production cycle, which means that coal from Rinat Akhmetov's mines goes to thermal power plants and Akhmetov factories; iron ores and steel are sent to smelters, which are also in the ownership of Akhmetov, and then the finished products goes to the world markets. Such a scheme allows to generate the majority of revenues under SCM. The division of the Donbass into two parts complicated the described scheme, as some SCM companies turned out to be on the occupied territories, and some in areas under Ukrainian control (Fig. 3).

Rinat Akhmetov, for some time, took a position of expectation, he did not give any comments about the war or peace, as a result of the blockade of Donbass, he lost most of his assets, but at the same time he was not the only businessman who faced this problem. Dmytro Firtash, Juchym Zviahilski and others are also on the list of "victims", but their assets are much smaller (Ivanenko 2017).

In the information dimension there were supporters and opponents of the blockade (Маслюченко 2017). All statements about the Donbass blockade can be divided according to the slogans that both opponents and blockers throw. In this context, there were a lot of speculations about whether it was possible to replace anthracite with other fuels or to bring it from other countries - for example: South Africa, Kazakhstan, Poland or Australia. The media that talked about 




Fig. 3. Economic relations of enterprises in the territories under control and outside the control of Ukraine Source: Golub 2017

Rys. 3. Stosunki gospodarcze przedsiębiorstw na terenach pod kontrolą i poza kontrolą Ukrainy

corruption, smuggling, victims of the war played an important role in creating such an opinion. Unfortunately there is lack of information resources that are ready to inform the viewer about the real state of affairs. In the media the situation concerning the blockade was commented on with extreme caution or was silenced (Dolzhenkova 2017). A discussion on this topic revealed several mutually exclusive views. To the question "Do you support the ORDLO blockage?"* (Chart 4), surveys of various TV channels showed that the opinions were divided and it was difficult to find an unambiguous answer without a thorough analysis of the situation. Opponents of the blockade regarded that, before the blockade, the mines in the occupied territories had a Ukrainian registration, therefore, miners were paid wages, they had work, enterprises paid taxes to the Ukrainian budget. After the start of the blockade, the authorities of self-proclaimed republics decided to nationalize Ukrainian enterprises (List of enterprises 2017). Thus, Ukraine got rid of strategically important enterprises, revenues to the budget and weakened control (actually lost) over the economy of the region. However, as the study shows, the Ukrainian society largely supports the blockade of Donbass. Supporters of the blockade claim that it is better to overpay for the import of coal than to continue to trade with the occupants. The main purpose of the blockade was to draw the attention of the public and the world to the trade with ORDLO rather than to cause the complete collapse of Ukrainian energy. Moreover, they demanded the release of prisoners of war, because this process was completely blocked. There is also a moral aspect of the blockade, the war almost daily collects human sacrifices, the plan from Minsk does not work, smuggling

\footnotetext{
* ORDLO - Certain regions of Donetsk and Luhansk regions.
} 


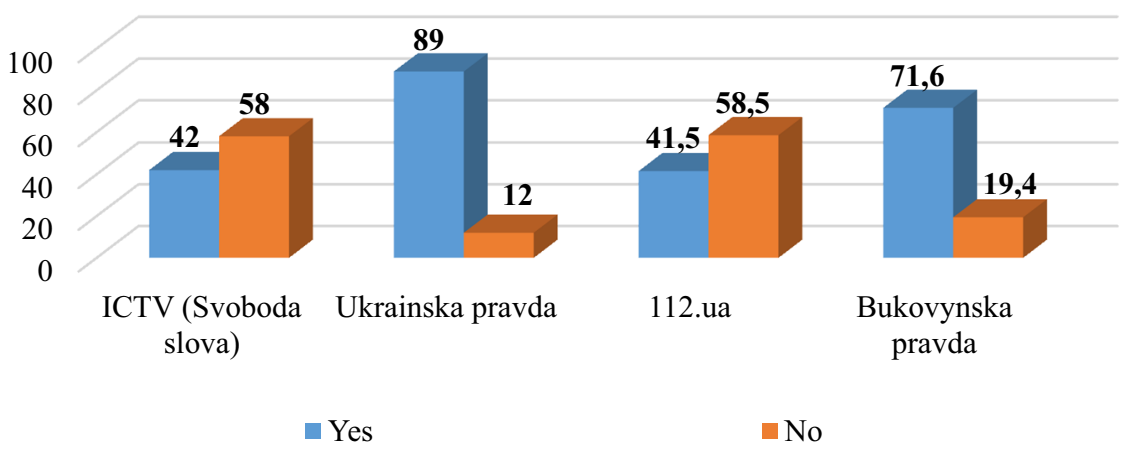

Chart 4. Do you support ORDLO blockage? Sources: own study based on: ORDLO Blockade 2017; More than half 2017

Wykres 4. Czy wspiera Pan/i blokadę ORDLO?

from Donbass continues, and the authorities are reporting that there is no opportunity to break economic relations with the occupied Donbass (Radchuk 2017).

\section{Position of ukrainian authorities, EU concerning the blockade of Donbass}

In the context of the Donbass' blockade, attention should be paid to the position of the Ukrainian authorities towards it. Volodymyr Groysman, Prime Minister of Ukraine, believes that there are no alternatives to anthracite from Donbass. He explains his position that replacing fuel of brand coal " $A$ " to brand coal "G" or replacing it with gas will lead to higher prices for heat and electricity (Alternatives 2017). Thus, the Prime Minister is looking for an easy way to fill the budget of Ukraine, and all proposed alternatives are associated with high costs and an increase in the budget deficit.

The Ukrainian authorities emphasize three main problems associated with the blockade of Donbass:

$\downarrow$ the purchase of coal abroad requires time, to bring it to Ukraine may take up to three months, and stocks at power stations quickly expire;

$\downarrow$ coal from alternative sources is more expensive, and funds for this are not provided for in the budget;

$\checkmark$ the coal mines that are situated in the occupied territories, are registered in the areas under the control of Ukraine, in the case of supply cessation, the miners who work there will remain without work and means for keeping families (Radchuk 2017). 
Representatives of the government, referring to international law, explain that mines in the occupied territories are the property of Ukraine, because when military operations began they were re-registered in Ukraine. In addition, it does not matter if these are private or public enterprises, because both the first and the second pay taxes to the Ukrainian budget. Taking into account that the Ukrainian budget in 2017 was passed with a deficit of UAH 77.5 billion into consideration, the lack of revenues from large taxpayers could have a significant negative impact on the budget, because it could have caused, for example, the underfunding of the army or the education system or health care, increase the inflation rate and lower the national currency rate. This situation could automatically lead to higher prices for food products and lower the standard of living.

The President of Ukraine turned out to be in a very unfavorable situation. The blockade was not agreed with the supreme state authorities. Prime Minister Grojsman's statement showed that authorities were against the blockade, but did not reveal their position publicly. The Ukrainian authorities failed to prevent the blocking of roads and railroads and did not dare to stop the blockade by force, because it could have caused a clash between the participants of the blockade and the security forces. Ukrainian authorities, instead of persuading or preventing a blockade, decided to support it.

The National Security and Defense Council of Ukraine decided to temporarily suspend transport connections with occupied Donbass. With such a decision of the Council of National Security and Defense, Petro Poroshenko restored some initiative in the East of Ukraine, as in the December-February activists were blocking railway connection and dictated the conditions concerning economic relations with the occupied Donbass, all of these had a negative impact on the image of the Ukrainian government and the President. Since the decision was adopted, the President became a co-organizer of the blockade at the state level. The role of activists who initiated and carried out the blockade and the president was equalized. The head of the state demonstrated its own position (to some extent imposed) concerning trade with the occupied territories (Demyanenko 2017).

In this context the security dimension, including the energy security of the state, is important. The number of people interested in illegal trade in Donbass was growing, the number of people who were interested in the end of the war was decreasing, which threatened to prolong it (Crossing 2018). The EU and the US recognized the blockade of Donbass as an unfavorable phenomenon and called for its abolition, because in their opinion the prolongation of the blockade could have serious consequences (US State 2017). According to the head of the EU mission in Ukraine, G. Mingarelli, the blockade of the railway, aggravated the conflict, increased the problems in the region, had a negative impact on the Ukrainian economy and did not contribute to its solution. Referring to the requirement to release political prisoners and prisoners of war, the ambassador noted that the blockade was not conducive to their release (EU Ambassador 2017). EU representatives considered economic and social ties with the occupied territories as one of the steps to further integrate or reintegrate these territories with Ukraine. If Kiev lost its ties with these territories, they would establish and strengthen it with Russia. As the situation in 2018 showed, H. Minarelli was right, because most of the economic ties were cut off, unemployment in 
the occupied territories increased, and the economy of Ukraine became sensitive and weakened (Gaevsky 2018). In addition, the coal of brand "A" was imported from Russia, which, according to statistics, became the main supplier of this type of fuel in 2017. It was not excluded that coal extracted in the uncontrolled territories of Donbass was imported from the Russian Federation, but with a margin and foreign currency (Gaevsky 2018).

\section{Conclusions}

The main purpose of the blockade was to stop trade with the occupied Donbass and release all prisoners of war. Unfortunately, from the very beginning it was clear that the leaders of the self-proclaimed republics were not able to perform these requirements, because the decision to release prisoners was taken in the Kremlin. The blockade had more negative consequences than positive ones, despite the fact that it was supported by the majority of the population. The suspension of trade with the occupied areas contributed to the crisis in the energy sector and deepened the social divide in the context of the situation in Donbass and the ways of its solution. The blockade showed that the majority of the population spoke out for the rejection of occupied territories and considered them "alien lands", which would never be "Ukrainian" due to mentality, political views, lack of a clearly defined identity.

Cutting off Donbass from the rest of the territory of Ukraine is difficult, it cannot be done only by stopping trade. Donbass is closely related to some Ukrainian regions and the activities of Ukrainian enterprises are linked to the production cycle, some of which are under occupation. There is an integrated infrastructure in Donbass, and if all the ties break right away, this will affect not only the economy of the occupied territories, but also the Ukrainian economy.

Summing up the year of the Donbass energy blockade, it should be stated that:

$\checkmark$ during the year Ukraine did not import the " $\mathrm{A}$ " brand coal from Donbass and replaced it with imported coal from other countries, where Russia was the dominant supplier;

$\checkmark$ the priority for the development of the coal sector in Ukraine has become a gradual pre-orientation of thermal power plants from the " $A$ " brand coal for the " $G$ " brand coal and modernization of the blocks taking into account these changes.

The situation around Donbass' blockade was quite complex and ambiguous. On the one hand, the requirements of the blockade participants to release political prisoners and prisoners of war and the desire to limit funding to the separatist regions was logical and justified. On the other hand, the arguments of the Ukrainian authorities that the " $\mathrm{A}$ " brand coal reserves were necessary to ensure the state's energy security, because it was cheaper compared to alternative coal supplies from other countries; the blockade had a negative impact on the budget of Ukraine. High support for blockade by Ukrainian society indicated that it had some claims to the authorities regarding "oligarch agreements with the leaders of self-proclaimed republics" about business interests. Al- 
though the Ukrainian government after the "nationalization" of the Ukrainian enterprises in the occupied territories had been the initiator of the blockade too, in terms of "hybrid" relationship with the self-proclaimed republics backed by Russia, it was difficult to find a simple and unique solutions to the problems (Demyanenko 2017).

\section{References}

112.ua 2017. More than half of Ukrainians do not support the railway blockade ORDLO (Bil'she polovyny ukrayintsiv ne pidtrymuyut' zaliznychnu blokadu ORDLO). [Online] https://ua.112.ua/ato/bilshe-polovyny-ukraintsiv-ne-pidtrymuiut-zaliznychnu-blokadu-ordlo-371293.html) [Accessed: 2017-11-03] (in Ukrainian).

Apostrophe 2017. List of enterprises "nationalized" by Zakharchenko in ORDLO is published (Opublikovano spysok pidpryyemstv, ,natsionalizovanykh” Zakharchenkom v ORDLO). [Online] https://apostrophe.ua/en/news/society/accidents/2017-03-03/opublikovan-spisok-predpriyatij-nacionalizirovannyh -zaharchenko-v- ordlo / 88659) [Accessed: 2017-03-03] (in Ukrainian).

BoBro, D. 2015. Coal industry of Ukraine in the conditions of hybrid war. Analytical note (Vuhil'na promyslovist' Ukrayiny v umovakh hibrydnoyi viyny. Analitychna zapyska). [Online] http://www.niss.gov. ua/articles/1890/ [Accessed: 2018-12-05] (in Ukrainian).

BP International Statistics Review 2017.

DemyanenKo, M. 2017. Some Political Aspects of the Donbass Trade Blockade in Expert Estimates (Deyaki politychni aspekty torhovel'noyi blokady Donbasu v otsinkakh ekspertiv). Resonance No. 19, p. 4-11 (in Ukrainian).

DolzHENKOVA, I. 2017. This is the mysterious word "blockade" (Tse zahadkove slovo "blokada"). [Online] http://detector.media/infospace/article/122835/2017-02-04-tse-zagadkove-slovo-blokada/ [Accessed: 2017-02-04] (in Ukrainian).

Dt.ua 2015. There are no mines producing anthracite for TPP under Kyiv control (Pid kontrolem Kyyeva ne zalyshylosya zhodnoyi shakhty, shcho dobuvaye antratsyt dlya TES). [Online] http://dt.ua/ECONOMICS/pid-kontrolem-kiyeva-ne-zalishilosya-zhodyy-shahti-scho-dobuvaye-antracit-dlya-tes-170417_. html [Accessed: 2015-04-20] (in Ukrainian).

DTEK 2017. DTEK announces about lost of management of enterprises located in the temporarily uncontrolled territory of Donetsk and Luhansk regions (DTÉK zayavlyaet o potere upravlenyya predpryyatyyamy, raspolozhennymyna vremenno nekontrolyruemoy terrytoryy Donetskoyy Luhanskoyoblasty). [Online] http://www.dtek.com/media-center/press/dtek-zayavlyaet-o-potere-upravleniya-predpriyatiyami-disposable-at-time-uncontrolled-territories-donetskoy-and-luganskoy-areas / [Accessed: 2017-03-15] (in Russian).

DTEK 2017. DTEK. Integrated report. Financial and non-financial results (Intehrovanyy zvit. Finansovi i nefinansovi rezul'taty). [Online] https://dtek.com/content/files/dtek_ar_2017_en1.pdf) [Accessed: 2018-11-09] (in Ukrainian).

GAEVSKY, D. 2018. Donbass trade blockade: what do we have a year later? (Torhovaya blokada Donbassa: chto imeem hod spustya). [Online] https://rian.com.ua/country/20180223/1032603367/blokada-Donbass-god.html) [Accessed: 2018-02-23] (in Russian).

Gorban, Y. 2017. "Indispensable" Donetsk coal? This is a one-year question ("Nezaminne" donets'ke vuhillya? Tse pytannya odnoho roku). [Online] https://www.ukrinform.ua/rubric-economics/2172979-nezaminne-donecke-vugilla-ce-pitanna-odnogo-roku.html [Accessed: 2017-02-09] (in Ukrainian). 
GORE, A. 2017. Blockade of ORDLO: targeted by fighters, but hit in Ukraine (Blokada ORDLO: tsilylysya u boyovykiv, a vluchyly v Ukrayinu). [Online] https://apostrophe.ua/ua/article/economy/2017-02-09/ blokada-ordlo-tselilis-v-boevikov-a -popali-po-ukraine / 10125 [Accessed: 2017-02-09] (in Ukrainian).

GULIA, O. 2017. Zmiyevskaya TPP undergoes reconstruction, or how to change anthracite to gas coal (Zmiyivs'ka TES prokhodyt' rekonstruktsiyu, abo yak zminyty antratsyt na hazove vuhillya). [Online] http://mind.kiev.ua/openmind/20170592-zmiyivska-tes-prohodit-rekonstrukciyu-abo-yak-zminiti-antracit- na-gazove-vugillya [Accessed: 2017-03-23] (in Ukrainian).

Golub, A. Hidden Beneficiary. What is the role of Akhmetov in economic cooperation with ORDILO (Neprykhovanyy benefitsiar. Yakoyu ye rol' Akhmetova v ekonomichniy spivpratsi z ORDiLO). [Online] http://m.tyzhden.ua/publication/185039 [Accessed: 2017-02-11] (in Ukrainian).

ICTV.ua 2017. Blockade ORDLO: Pros and Cons - Freedom of Speech (Blokada ORDLO: za i proty - Svoboda slova). [Online] http://svoboda.ictv.ua/en/videos/blokada-ordlo-za-i-proty-svoboda-slova-30-01-2017/) [Accessed: 2017-01-30] (in Ukrainian).

IVANENKO, S. 2017. So who has suffered from the "nationalization" of enterprises by militants (infographic) (Tak khto zh postrazhdav vid "natsionalizatsiyi" pidpryyemstv boyovykamy (infohrafika)) [Online] http://patrioty.org.ua/blogs/tak-khto-zh-postrazhdav-vid-natsionalizatsii-pidpryiemstv-boiovykamy-infohrafika -160456.html [Accessed: 2017-03-04] (in Ukrainian).

Izviestiya.ru2017. EU ambassador in Kiev criticized the Donbass tradeblockade(PosolESvKyeveraskrytykoval torhovuyu blokadu Donbassa). [Online] https://iz.ru/news/670220) [Accessed: 2017-03-11] (in Russian).

KaZANSKY et al. 2017 - KaZAnsky, D., NeKrasova, A., SAVitsky, O., PaVlov, Y., SMirnov, P., TARABAnova, S. and Yanova, G. 2017. The Real Cost of Coal in Donbass War: A Look Through the Prism of Human Rights (Spravzhnya tsina vuhillya v umovakh viyny na Donbasi: pohlyad kriz' pryzmu prav lyudyny), ed. A. Nekrasova and V. Shcherbachenko, NGO "East Ukrainian Center for Public Initiatives", Kyiv 2017, Publishing House of ART BOOK LLC, 140 pp. (in Ukrainian).

Kreston-gcg 2017. Overview of the Ukrainian Energy Coal Market. [Online] https://kreston-gcg.com/ wp-content/uploads/coal.pdf [Accessed: 2018-11-12].

Lenta.ru 2017. US State Department has warned about the serious consequences of the transport blockade of the Donbass (Hosdep SSHA predupredyl o ser'eznykh posledstvyyakh transportnoy blokady Donbassa). [Online] https://lenta.ru/news/2017/03/17/gosdep_blokada_donbassa/) [Accessed: 2017-03-17] (in Russian).

MASLYUCHENKO, S. 2017. Information wars around the "ORDLO blockade" (Informatsiyni viyny navkolo "blokady ORDLO"). [Online] http://hvylya.net/analytics/politics/informatsiyni-viyni-navkolo-blokadi-ordlo.html [Accessed: 2017-02-19] (in Ukrainian).

Panoptikon.org 2017. Text Chronicle of the Donbass Blockade (Tekstovaya khronyka blokady Donbasa). [Online] http://panoptikon.org/articles/90629-khronika-blokady-donbassa-obnovljaetsja.html [Accessed: 2017-02-17] (in Russian).

PYvOVAROV, S. 2017. Lugansk and Slavyanskaya TPP can be stopped due to the blockade of the railway (Luhans'ka i Slov"yans'ka TES mozhut' zupynytys' cherez blokadu zaliznytsi). [Online] https://hromadske.ua/posts/luhanska-i-slovianska-tes-mozhut-zupynytys-cherez-blokadu-zaliznytsi [Accessed: 2017-02-01] (in Ukrainian).

POPOVYCH, I., 2013. State and prospects of development of the coal industry of Ukraine (Sostoyanye y perspektyvy razvytyya uhol'noy promyshlennosty Ukrayny). Coal of Ukraine No. 10, p. 3-6 (in Ukrainian).

RADCHUK, O. 2017. Blockade Syndrome: The Political Consequences of Donbass Trade Isolation (Blokadnyy syndrom: pro politychni naslidky torhovoyi izolyatsiyi Donbasu). [Online] https://www.slovoidilo. ua/2017/02/15/kolonka/aleksandr-radchuk/polityka/blokadnyj-syndrom-pro-politychni-naslidky -torhovoyi-izolyacziyi-donbasu [Accessed: 2017-02-15] (in Ukrainian). 
SCM 2017. DTEK. Energy. [Online] http://www.scm.com.ua/en/business/sectors/electric/ [Accessed: 2017-05-10].

SCM 2017. SCM Group declares complete loss of control over all Group assets located in the temporarily uncontrolled territories of Donetsk and Luhansk regions (Hrupa SKM zayavlyaye pro povnu vtratu kontrolyu nad usima aktyvamy Hrupy, shcho roztashovani na tymchasovo nekontrol'ovanykh terytoriyakh Donets'koyi ta Luhans'koyi oblastey). [Online] http://rebuild.scm.com.ua/en/2017/03/15/grupa- skmzayavlyaie-pro-povnu-vtratu-kon / [Accessed: 2017-03-15] (in Ukrainian).

Slovoidilo 2017. There is no alternative to coal from uncontrolled territories - Groisman (Al'ternatyvy vuhillyu z nepidkontrol'nykh terytoriy nemaye - Hroysman). [Online] https://www.slovoidilo. ua/2017/02/13/novyna/polityka/alternatyvy-vuhillyu-z-nepidkontrolnyx-terytorij-nemaye-hrojsman [Accessed 2017-02-03] (in Ukrainian).

Slovoidilo 2017. In Lugansk region, unknown people blew up a railway track - photo (U Luhans'kiy oblasti nevidomi pidirvaly zaliznychnu koliyu - foto). [Online] https://www.slovoidilo.ua/2017/01/30/novyna/ suspilstvo/u-luhanskij-oblasty-nevidomi-pidirvaly-zaliznychnu-kolyu-nardep [Accessed: 2017-01-20] (in Ukrainian).

SOKOLOV, S. 2017. The Government of Ukraine has introduced a state of emergency in the energy sector (Uryad Ukrayiny zaprovadyv nadzvychaynyy stan v enerhetytsi) http://www.dw.com/en/government-Ukraine- has introduced- an extraordinary- station-in-energy/a-3756646 [Accessed: 2017-02-15] (in Ukrainian).

SOLONYNA, E. 2017. What will replace anthracite: a peaceful atom, imported coal and water (Chym zaminyat' antratsyt: myrnyy atom, importne vuhillya $i$ voda). [Online] https://www.radiosvoboda. org/a/28315780.html [Accessed: 2017-02-18] (in Ukrainian).

Transparency International 2017. Crossing the Border: Illegal Trade with occupied Donbass (Peretynayuchy mezhu: nelehal'na torhivlya z okupovanym Donbasom, shcho pidryvaye oboronu). [Online] https://nako.org.ua/wp-content/uploads/2017/11/Peretynayuchy-mezhu.-Nelehalna-torhivlya-z- okupovanym-Donbasom-scho-pidryvaje -.... pdf) [Accessed: 2018-11-12] (in Ukrainian).

UNIAN.ua 2018. Centrenergo TPP units operate exclusively on gas coal (Enerhobloky TES „Tsentrenerho" pratsyuyut' vyklyuchno na hazovomu vuhilli). [Online] https://economics.unian.ua/energetics/ 10119149-energobloki-tes-centrenergo-pracyuyut-viklyuchno-na-gazovomu-vugilli.html [Accessed: 2018-12-11] (in Ukrainian).

UNIAN.ua 2018. DTEK announces the results of an anthracite coal-fired TPP unit conversion program (U DTEK rozpovily pro rezul'taty prohramy z perevedennya enerhoblokiv TES z antratsytu na hazove vuhillya). [Online] https://economics.unian.ua/energetics/10337124-u-dtek-rozpovili-pro-rezultati-programi-z -perevedennya-energoblokiv-tes-z-anthracitu-na-gazove-vugillya.html [Accessed: 2018-11-14] (in Ukrainian).

ZAKHARCHENKO, A. 2017. The ORDLO Blockade: A Hybrid Political Struggle (Blokada ORDLO: hibrydna politychna borot'ba). [Online] http://www.pravda.com.ua/columns/2017/03/6/7137240/) [Accessed: 2017-03-06] (in Ukrainian). 
Oksana VOYTYUK

\title{
Energetyczna blokada Donbasu oraz jej skutki
}

\begin{abstract}
Streszczenie
Aneksja Krymu i rozpoczęcie działań wojennych w Donbasie w kwietniu 2014 r. były przyczyną rosnącego zagrożenia bezpieczeństwa energetycznego Ukrainy. Pod względem dostaw węgla Donbas ma kluczowe znaczenie dla gospodarki kraju. Działania wojenne spowodowały wzrost nielegalnego wydobycia i nielegalnego handlu węglem. Sytuacja ta spowodowała nasilenie niezadowolenia społecznego, szczegolnie wśród uczestników batalionów ochotniczych, którzy brali udział w operacjach wojskowych w Donbasie i byli inicjatorami blokady Donbasu. Sytuacja wokół blokady Donbasu jest dość złożona i niejednoznaczna. Z jednej strony wymagania uczestników blokady, aby uwolnić więźniów politycznych i jeńców wojennych, a także ograniczyć finansowanie regionom separatystycznym jest logiczna i uzasadniona. Z drugiej strony istnieją twarde argumenty władzy ukraińskiej o tym, że dostawy węgla marki „A” nie można powstrzymać, gdyż są one niezbędne dla zapewnienia bezpieczeństwa energetycznego państwa. Głównym powodem było to, że zasoby $\mathrm{z}$ terenów okupowanych są tańsze w porównaniu $\mathrm{z}$ alternatywnymi dostawami węgla $\mathrm{z}$ innych państw. Blokada Donbasu negatywnie odbiła się na budżecie Ukrainy. Wysokie wsparcie blokady przez społeczeństwo ukraińskie świadczy o tym, iż ma ono pewne roszczenia do władzy dotyczące „porozumień oligarchów z liderami samozwańczych republik" o interesach biznesowych. Pomimo że ukraiński rząd po „nacjonalizacji” ukraińskich przedsiębiorstw na terenach okupowanych sam został inicjatorem blokady, w kwestii „hybrydowych” relacji z samozwańczymi republikami wspieranymi przez Rosję, trudno znaleźć proste i unikalne rozwiązanie problemu. Najważniejszym celem artykułu była analiza specyfiki rozwoju przemysłu węglowego na Ukrainie oraz głównych przyczyn blokady Donbasu i jej konsekwencji.
\end{abstract}

SŁoWA KLUCZOWE: blokada, Donbas, Ukraina, węgiel 
